\title{
EVALUASI PELAKSANAAN KESELAMATAN PASIEN (PASIEN SAFETY) DI RUMAH SAKIT UMUM DAERAH LABUANG BAJI MAKASSAR
}

\author{
Annisa Isti Haritsa ${ }^{1 *}$, Yasir Haskas ${ }^{2}$ \\ 1*. STIKES Nani Hasanuddin Makassar, Jl. Perintis Kemerdekaan VIII No. 24, Kota Makassar, Indonesia, 90245 \\ 2. STIKES Nani Hasanuddin Makassar, Jl. Perintis Kemerdekaan VIII No. 24, Kota Makassar, Indonesia, 90245 \\ *e-mail :Annisaistiharitsa_mahful@yahoo.com / 085213928405
}

(Received: 29-06-2021 ; Reviewed: 30-06-2021 ; Accepted: 05-07-2021)

\begin{abstract}
Patient safety is a variable to measure and evaluate the quality of nursing services that have an impact on health services. The purpose of this study was to evaluate the implementation of patient safety in the inpatient room of the Labuang Baji Regional General Hospital, Makassar. The type of research used is descriptive quantitative method with observational techniques. The sampling method used with purposive sampling technique obtained a sample of 70 respondents according to the inclusion criteria. Data collection is done by using observation sheets. The results of the research on Evaluation of Patient Safety Implementation at Labuang Baji Hospital showed that of the 70 respondents who had identified the patient, as many as 70 respondents (100\%). Effective communication 70 respondents (100\%). Increased drug safety as many as 66 respondents (94.3\%) have implemented drug safety and 4 respondents $(5.7 \%)$. The accuracy of the patient, the right location, and the right operating procedure 70 respondents (100\%). Reducing the risk of infection by 67 respondents (95.7\%) and 3 respondents (4.3\%). The reduction in the risk of falling patients was 64 respondents (91.4\%) and 6 respondents (8.6\%) did not do it.
\end{abstract}

Keywords: Patient Safety, Six Patient Safety Goals

\begin{abstract}
Abstrak
Keselamatan pasien (patient sefety) merupakan suatu variabel untuk mengukur dan mengevaluasi kualitas pelayanan keperawatan yang berdampak terhadap pelayanan kesehatan. Tujuan penelitian ini ialah untuk mengevaluasi pelaksanaan keselamatan pasien di ruang inap Rumah Sakit Umum Daerah Labuang Baji Makassar. Jenis penelitian yang digunakan ialah metode deskriktif kuantitatif dengan tehnik observasional. Metode sampling yang digunakan dengan tehnik purposive sampling didapatkan sampel 70 responden sesuai dengan kriteria inklusi. Pengumpulan data dilakukan dengan menggunakan lembar observasi. Hasil penelitian Evaluasi Pelaksanaan Keselamatan Pasien di RSUD Labuang Baji menunujukkan bahwa dari 70 responden yang telah melakukan identifikasi pasien yaitu sebanyak 70 responden (100\%). Komunikasi efektif 70 reponden $(100 \%)$. Peningkatan keamanan obat sebanyak 66 responden $(94,3 \%)$ telah melakukan keamanan obat dan yang tidak melakukan 4 responden $(5,7 \%)$. Ketepatan pasien, tepat lokasi, dan tepat prosedur operasi 70 responden $(100 \%)$. Pengurangan resiko infeksi serbanyak 67 responden $(95,7 \%)$ dan yang tidak melakukan yaitu sebanyak 3 responden $(4,3 \%)$. Pengurangan resiko pasien jatuh sebanyak 64 responden $(91,4 \%)$ dan yang tidak melakukan yaitu sebanyak 6 responden $(8,6 \%)$.
\end{abstract}

Kata Kunci: Keselamatan Pasien, Enam Sasaran Keselamatan Pasien 


\section{Pendahuluan}

Kualitas merupakan fenomena yang konprehensif dan multi dimensi kegiatan menjaga mutu dapat menyangkut satu atau beberapa dimensi, salah satunya keamanan (Lori De Pree Brown dalam Astuti 2016).

Keselamatan pasien (patient sefety) merupakan suatu variabel untuk mengukur dan mengevaluasi kualitas pelayanan keperawatan yang berdampak terhadap pelayanan kesehatan. Program keselamatan pasien adalah suatu usaha untuk menurunkan angka kejadian tidak di harapkan yang sering terjadi pada pasien selama di rawat di rumah sakit sehingga sangat merugikan baik pasien itu sendiri maupun pihak rumah sakit. Kejadian tidak diharapkan bisa disebabkan oleh berbagai faktor antara lain beban kerja perawat yang tinggi, alur komunikasi yang kurang tepat, penggunaan sarana kurang tepat, dan sebagainya. (Nursalam, 2016)

Dalam Permenkes 1691/Menkes/Per/ VIII/ 2011 menyatakan bahwa setiap rumah sakit wajib mengupayakan pemenuhan sasaran keselamatan pasien. Keselamatan pasien rumah sakit merupakan sistem rumah sakit membuat asuhan pasien lebih aman meliputi asesmen resiko, identifikasi dan pengelolahan hal yang berhubungan dengan resiko pasien pelaporan dan analisis insiden, kemampuan belajar dari insiden dan tindaklanjutnya serta implementasi solusi untuk meminimalkan timbulnya resiko dan mencegah terjadinya cedera yang disebabkan oleh kesalahan akibat melaksanakan suatu tindakan atau tidak mengambil tindakan yang seharusnya diambil (Huges 2008 dalam Putri 2016 ).

Beberapa istilah yang digunakan dalam keselamatan pasien antara laian: kejadian tidak diharapkan ( adverse avent), Kejadian nyaris cedera ( near miss), kejadian tidak cedera, kondisi potensial cedera, kejadian sentinel.

Menurut Iswati, 2013 menjelaskan bahwa rumah sakit merupakan tempat yang rentan terjadinya infeksi nosokomial atau infeksi baru selama perawatan berlangsung. Dimana Angka kejadian nosocomial berdasarkan standar Permenkes (2010) yaitu <1,5\%. Sebuah penelitian mngungkapkan bahwa dengan mencuci tangan dapat menurunkan 20\% - 40\% kejadian infeksi nosocomial (Seragih, 2014).

Keselamatan pasien di rumah sakit sampai saat ini masih menjadi masalah global, Menurut Suharjo yang mengutip dari Health Grades Inc pada tahun 2004 Amerika Serikat banyak kehilangan penduduknya akibat kejadian tidak diharapkan (KTD) yang terjadi hampir setiap bulan, jumlahnya melebihi seluruh korban perang Vietnam. Akibat sering terjadi kesalahan medis tersebut akan berdampak pada banyaknya tuntutan hukum terhadap rumah sakit. Dan dari beberapa negara telah melaporkan ke Joint Commission Internasional ( JCI) \& World Health Organitation (WHO) dimana terdapat $70 \%$ kejadian kesalahan pengobatan meskipun, JCI \& WHO mengeluarkan "Nine Life -Saving Patient. Safety Solution " atau 9 solusi keselamatan pasien. Namun kenyataannya, permasalahan keselamatan pasien masih banyak terjadi termasuk di Indonesia (JCI, 2011).

Di Indonesia Gerakan Patient safety diawali dengan membentuk Komite Patient safety Rumah Sakit / KKPRS sebagai hasil Raker PERSI Maret 2005 di Surabaya, diikuti dengan perancangan Gerakan Patient safety rumah sakit. Keselamatan pasien merupakan salah satu komponen standar penilaian dalam akreditasi rumah sakit dan diatur dalam Peraturan Menteri Kesehatan No. 1691 tahun 2011. Keselamatan pasien di rumah sakit terdiri dari 6 sasaran meliputi: ketepatan identifikasi pasien, peningkatan komunikasi yang efektif, peningkatan keamanan obat yang perlu diwaspadai, kepastian tepat lokasi, tepat prosedur, tepat pasien operasi, pengurangan risiko infeksi terkait pelayanan kesehatan, pengurangan risiko jatuh (Uminingsih, 2016).

Sejak terbentuknya komite patient safety di laporkan insiden di Indonesia sejak tahun 2012 tercatat data kunjungan rawat jalan sebesar 245.323 pasien dengan rata-rata 817 per hari. Pelaporan insiden keselamatan pasien yang masuk ke KKPRS mulai tahun 2011-2013 adalaha tahun2011 sebanyak 19 laporan, tahun 2012 sebnyak 14 laporan, dan tahun 2013 sebnayk 41 laporan.

Dari laporan diatas insiden keselamatan pasien berdasarkan provinsi sebanyak 145 insiden yang terdiri dari KTD 46\% dan KTC 48\% dan lain-lain 68\%. Adapun data yang di temukan DKI Jakarta 37.9\%, Jawa Tengan $15.9 \%$, Yogyakarta $13.8 \%$, Jawa Timur $11.7 \%$, Sumatra Selatan $6.9 \%$, Jawa barat 2.8\%, Bali $1.4 \%$, Sulawesi selatan $0.69 \%$, dan Aceh $0.68 \%$. ( KKPS 2012 ). Namun data yang di temuka di Indonesia catatan kejadian yang terjadi di rumah sakit belum di kembangakan dengan keseluruhan sehingga kejadian yang terjadi pada pasien dengan keselamatan pasien masih memiliki keterbatasan.

Menurut Meliana (2014) di Rumah Sakit Stella Maris dari laporan pencatatan patient safety tahun 2013. Setidaknya ada tiga belas jenis insiden keselamatan pasien diantaranya : salah pemberian obat dari bagian farmasi (16\%), salah pemberian obat di rawat inap (6\%), salah diagnose $(6 \%)$, salah distribusi obat dari farmasi (13\%), nyaris salah aplosing obat (3\%), salah interpretasi (3\%), salah mengetik hasil lab/RO (6\%), salah menyediakan obat $(3 \%)$, pasien jatuh $(9 \%)$, kejadian potensial cidera $(9 \%)$, kejadian sentinel $(3 \%)$, salah mengambil obat (3\%) dan KTD lain (14\%). Pada triwulan 1 Januari- April 2011, laporan insiden keselamatan pasien dari KKP-RS didapatkan 34 laporan insiden, dan sebanyak 19,58\% tim keperawatan memiliki andil dalam keselamatan pasien hal ini karenakan perawat memiliki waktu yang lebih lama dalam memberikan asuhan keperawatan pada pasien.

Pada data awal dari Komite Keselamatan Pasien di RSUD Labuang Baji terdapat beberapa kejadian. Di dapatkan dari tahun 2015 terdapat 9 kasus tenaga kesehatan yang terkena jarum suntik dan jarum infuse hingga 
jarum pada saat melakukan tindakan operasi, dan pada tahun 2016 ada 2 (dua) kasus yaitu pada bulan Januari dan September, dan pada tahun 2017 terdapat 2 kasus yaitu pada bulan Mei dan September.

Kejadian tertusuk jarum pada saat melaksanakan tindakan merupakan salah satu dari kejadian tidak terduga (KTD) dari keselamatan pasien. Dari hasil wawancara tim Komite Keselamtan Pasien di RSUD labuang baji sudah berjalan, yaitu dengan memberikan gelang sebagai penanda / identitas pasien, dengan memeberikan informat consent sebelum dan sesudah melakukan tindakan, membedakan kotak obat antara pasien yang satu dengan pasien yang lainnya. Dengan menjalankan program keselamatan pasien, visi dan misi suatu rumah sakit dapat berjalan dengan lancar dengan pelayanan yang terprogram. Dan dapat memberikan kepercayaan kepada masyarakat terhadap pelayanan kesehatan suatu rumah sakit.

Menurut Wibowo 2014 yang menjadi salah satu sumber peningkatan keselamatan pasien adalah motivasi yang merupakan faktor pendukung penting yang harus dimiliki oleh setiap perawat karena motivasi yang baik dapat membawa seseorang melakukan suatu tindakan yang baik. Serta bagaimana petugas kesehatan melaksanakan program - program perencanaan tercapainya patient safety.

Berdasarkan uraian diatas peneliti tertarik untuk melakukan penelitian tentang "Evaluasi Pelaksanaan Keselamatan Pasien di RSUD Labuang Baji Kota Makassar"

\section{Metode}

\section{Lokasi, Populasi, Sampel}

Jenis penelitian ini adalah Penelitian Deskriptif Kuantitatif dengan metode penelitian Observasional. Penlitain ini dilakukan di Rumah Sakit Labuang Baji Makassar Tahun 2017.Populasi dalam penlitian ini adalah seluruh perawat rawat inap Rumah Sakit Labuang Baji Makassar yang berjumlah 237 orang.Jumlah sampel dalam penelitian ini sebanyak 70 orang, teknik pengambilan sampel menggunakan tehnik purposive sampling

1. Kriteria Inklusi

a. Responden yang tersedia berpartisipasi dalam penelitian.

b. Perawat yang sedang aktif dalam pelayanan kesehatan.

c. Perawat yang sedang tidak memiliki masalah kedinesan

2. Kriteria Ekslusi

a. Perawat yang sedang cuti.

b. Perawat yang sedang dalam keadaan sakit

\section{Pengumpulan Data}

1. Data primer

Pengumpulan data primer di lakukan melalui metode observasi dan dengan menggunakan lembar obsevasional bersumber dari KARS.Data primer yang lain diperoleh melalui observasi mengenai fasilitas dan perlengkapan keselamatan pasien.

2. Data sekunder

Data sekunder penelitian ini diperoleh dari bagian kepegawaian RSUD Labuang Baji Makassar.

Pengolahan Data

1. Editing

Editing adalah upaya untuk memeriksa kembali kebenaran data yang diproleh atau dikumpulkan.

2. Coding

Coding merupakan kegiatan pemberian kode numeric (angka) terhadap data yang terdiri atas beberapa kategori

3. Data Entry

Data Entry adalah kegiatan memasukkan data yang telah dikumpulkan kedalam master tabel atau database computer

4. Melakukan Teknik Analisis

Melakukan teknik analisis yang disesuaikan dengan jenis penelitian (Hidayat, 2014).

Anlisis Data

Analisis univariat yaitu analisa yang digunakan untuk menganalisis variabel yang ada secara deskriktif dengan membuat tabel distribusi frekuensi. Variabel yang di deskripsikan dalam penelitian ini adalah variabel. 


\section{Hasil}

1. Analisis Univariat

a. Identifikasi Pasien Secara Benar

Tabel 1 Distribusi Frekuensi Berdasarkan Identifikasi Pasien Di RSUD Labuang Baji Makassar

\begin{tabular}{|c|c|c|}
\hline Identifikasi Pasien & Frekuensi & Persentase \\
\hline Dilakukan & 70 & $100 \%$ \\
\hline Tidak dilakukan & 0 & 0 \\
\hline Jumlah & 70 & $100 \%$ \\
\hline
\end{tabular}

Dari data 1 menunjukkan bahawa dari 70 responden di dapatkan 70 (100\%) responden telah melakukan identifikasi pasien.

b. Komunikasi Efektif

Tabel 2 Distribusi Frekuensi Berdasarkan Komunikasi Efektif Di RSUD Labuang Baji Makassar

\begin{tabular}{|c|c|c|}
\hline Komunikasi Efektif & Frekuensi & Persentase \\
\hline Dilakukan & 70 & $100 \%$ \\
\hline Tidak dilakukan & 0 & 0 \\
\hline Jumlah & 70 & $100 \%$ \\
\hline
\end{tabular}

Dari data 2. menunjukkan bahawa dari 70 responden di dapatkan 70 (100\%) responden telah melakukan komunikasi efektif.

c. Keamanan Obat

Tabel 3 Distribusi Frekuensi Berdasarkan Keamanan Obat Di RSUD Labuang Baji Makassar

\begin{tabular}{|c|c|c|}
\hline Keamanan Obat & Frekuensi & Persentase \\
\hline Dilakukan & 66 & $94,3 \%$ \\
\hline Tidak dilakukan & 4 & 5,7 \\
\hline Jumlah & 70 & $100 \%$ \\
\hline
\end{tabular}

Dari data 3 menunjukkan bahawa dari 70 responden di dapatkan 66 (94,3\%) responden telah melakukan keamanan obat, sedangkan yang tidak melakukan keamanan obat yaitu $4(5,7 \%)$ tidak ada.

d. Tepat Lokasi, Tebat Pasien, dan Tepat Prosedur Operasi

Tabel 4 Distribusi Frekuensi Berdasarkan Tepat Lokasi, Tebat Pasien, Tepat Prosedur Operasi Di RSUD Labuang Baji Makassar

\begin{tabular}{|c|c|c|}
\hline $\begin{array}{c}\text { Tepat Lokasi, Tebat Pasien, dan } \\
\text { Tepat Prosedur Operasi }\end{array}$ & Frekuensi & Persentase \\
\hline Dilakukan & 70 & $100 \%$ \\
\hline Tidak dilakukan & 0 & 0 \\
\hline Jumlah & 70 & $100 \%$ \\
\hline
\end{tabular}

Dari data 4 menunjukkan bahawa dari 70 responden di dapatkan 70 (100\%) responden telah melakukan Tepat Lokasi, Tebat Pasien, dan Tepat Prosedur Operasi dengan baik.

e. Pengurangan Resiko Infeksi

Tabel 5 Distribusi Frekuensi Berdasarkan Resiko Infeksi di RSUD Labuang Baji Makassar

\begin{tabular}{|c|c|c|}
\hline Pengurangan resiko infeksi & Frekuensi & Persentase \\
\hline Dilakukan & 67 & $95,7 \%$ \\
\hline Tidak dilakukan & 3 & $4,3 \%$ \\
\hline Jumlah & 70 & $100 \%$ \\
\hline
\end{tabular}

Dari data 5 menunjukkan bahawa dari 70 responden yang terbanyak melakukan pengurangan resiko infeksi yaitu sebanyak 67 responden $(95,7 \%)$. Sedangkan yang tidak melakukan pengurangan resiko infeksi yaitu sebanyak 3 responden $(4,3 \%)$. 
f. Pengurangan Resiko Pasien Jatuh

Tabel 6 Distribusi Frekuensi Berdasarkan Pengurangan Resiko Pasien Jatuh Di RSUD Labuang Baji Makassar

\begin{tabular}{|c|c|c|}
\hline Pengurangan Resiko Paien Jatuh & Frekuensi & Persentase \\
\hline Dilakukan & 64 & $91,4 \%$ \\
\hline Tidak dilakukan & 6 & $8,6 \%$ \\
\hline Jumlah & 70 & $100 \%$ \\
\hline
\end{tabular}

Dari data 6 menunjukkan bahawa dari 70 responden yang terbanyak melakukan pengurangan resiko pasien jatuh yaitu sebanyak 64 responden $(91,4 \%)$, Sedangkan yang tidak melakukan pengurangan resiko pasien jatuh yaitu sebanyak 6 responden $(8,6 \%)$.

\section{Pembahasan}

Keselamatan pasien adalah proses yang dijalankan oleh organisasi yang bertujuan membuat layanan kepada pasien menjadi lebih aman, proses tersebut mencakup pengkajian resiko, identifikasi dan pengolaan resiko pasien, pelaporan dan analisis insiden, kemampuan belajar dari suatu keadaan atau kejadian, dan mererapkan solusi yang tepat untuk mengurangi resiko tersebut terjadi kembali (Cenderasuci, 2012)

American Hospital Asosiation (AHA) Broad of Trustees mengidentifikasikan bahwa keselamatan dan keamanan pasien (pasien safety) merupakan suatu prioritas yang strategis. Mereka juga menetapka capaian peningkatan yang terukur untuk medication safety sebagai target utamanya.

1. Identifikasi Pasien

Hasil penelitian yang didapatkan berdasarkan tabel 1 tentang pelaksanaan keselamatan pasien menunjukkan bahwa ketepatan identifikasi pasien sudah terlaksana dengan baik, diketahui bahwa dari 70 responden didapatkan 70 responden $(100 \%)$ telah melakukan identifikasi pasien dengan baik.

Hal ini berdasarkan dari hasil observasi ditemukan bahwa responden telah menerapkan penggunaan gelang identitas, gelang identitas disesuaikan dengan kondisi pasien yang terdiri dari gelang warna pink untuk perempuan, gelang warna biru untuk pasien laki-laki, pada pasien yang mempunyai riwayat alergi menggunakan gelang warna merah, dan ungu pada pasien yang tidak boleh di resusitasi, dan warna kuning untuk pasien resiko jatuh.

Pada gelang identifikasi sudah tercamtun nama, umur, nomor rekam medik serta tanggal lahir pasien, yang mana gelang ini di pasangkan saat pasien pertama kali masuk yaitu di UGD. Tujuan pemasangan gelang identitas yaitu agar petugas dapat membedakan antara pasien satu dengan yang lainnya. Serta mempermudah petugas mengidentikasi pasien sebelum melakukan tindakan maupun pemberian keperawatan baik pemasangan infus, pengambilan darah, pemberian obat, maupun pemberian perawatan lainnya.

Pengecekan identitas pasien dilakukan pada saat sebelum melakukan tindakan invasif di ruang rawat inap maupun rawat jalan, sebelum pemberian obat, sebelum pengambilan darah, dan sebelum pemberian transfusi darah. Pelepasan atau pergantian gelang identitas pasien dilakukan bila gelang rusak, bila tulisan atau tinta identitas sudah tidak jelas terbaca, pasein yang pada awalnya tanpa identitas dan sudah ditemukan identitasnya yang jelas dan benar, pasien sudah boleh pulang atau meninggal, gelang dilepas oleh perawat atau bidan dengan cara menggunting gelang pada saat pasien diijinkan pulang atau bila meninggal, gelang dilepaskan setelah serah terima jenazah dikamar jenazah.

Menurut Joint Communission Internasional (JCI) mengidentifikasi pasien dilakukan sejak awal masuk Rumah Sakit dengan dua identitas, nama dan nomor rekam medis yang telah tertera di gelang pasien dan pada saat pemasangan gelang pasien akan dijelaskan oleh perawat manfaat gelang dan resiko yang akan timbul jika tidak pasang gelang identitas.

Hal ini sejalan dengan sistem identifikasi pasien di RSUP Prof. Kandou Manado sudah menjadi rumah sakit yang terakreditasi dalam sistem akreditasi KARS 2012, dimana penerapan identifikasi pasien di lakukan sejak pasien mendaftar identitas pasien meliputi: nama, umur, dan nomor rekam medis pasien. Kemudian identitas tersebut dicetak pada stiker yang selanjutnya ditempelkan pada gelang identitas pasien, status dan catatan medis.

2. Komunikasi Efektif

Hasil penelitian yang didapatkan berdasarkan tabel 2 tentang pelaksanaan keselamatan pasien menunjukkan bahwa komunikasi efektif sudah terlaksana dengan baik, diketahui bahwa dari 70 responden didapatkan 70 responden (100\%) telah melakukan komunikasi efektif dengan baik.

Hal ini berdasarkan dari hasil observasi ditemukan bahwa responden sudah menerapkan komunikasi efektif dengan baik, penyampaian pesan yang didokumentasi dan diverifikasi baik komunikasi efektif secara langsung maupun komunikasi efektif tidak langsung atau via telpon dengan tehnik SBAR (Situation, Bacround, Assesment, Recomendation) dan TBAK ( Tulis, Baca, Konfirmasi). 
Komunikasi efektif secara langsung di lakukan pada saat visite dimana dokter memberikan instruksi kepada perawat kemudian dituliskan atau mendokumentasikan di catatan perkembangan pasien. Setelah itu isntruksi di bacakan ulang kepada pemberi pesan dalam hal ini dokter untuk diverifikasi kembali, kemudian meminta dokter untuk menandatangani instruksi tersebut.

Komunikasi efektif secara tidak langsung yaitu komunikasi yang dilakukan secara lisan melalui via telepon antara perawat dengan dokter yang dimana dokter memberikan instruksi kepada perawat kemudian dituliskan secara lengkap dicatatan perkembangan, kemudian dibacakan kembali oleh penerima instruksi dalam hal ini perawat. Kemudian instruksi di verifikasi kembali oleh individu yang memberikan perintah dalam hal ini dokter dengan cara meminta tanda tangan pada catatan perkembangan pasien.

Komunikasi efektif dilakukan dengan tepat waktu, akurat, lengkap, jelas, dan mudah dipahami oleh pihak terkait dimana tujuannya untuk mengurangi kesalahan dan menghasilkan peningkatan keselamatan pasien. SBAR ( Situation, Background, Assesmen, Recommendation) digunakan untuk melaporkan keadaaan pasien atau kondisi kritis / pasien baru.

SBAR (Situation, Background, Assesmen, Recomendation), yang dimaksudkan dalam pelaporan Situation yaitu nama, tanggal lahir, kondisi terkait permasalahan pasien, masalah yang mulai atau belum terjadi. Background yaitu: tanggal masuk rumah sakit, diagnosa awal, keluhan utama, intervensi yang telah dilakukan, respon pasien, riwayat alergi, riwayat pembedahan. Assesmen yaitu: tanda - tanda vital, skore nyeri, resiko jatuh, status nutrisi, riwayat tindakan, pengobatan, hal kritis, dan informasi klinik lainnya yang mendukung. Rekommendation yaitu: rekomendasi sebagai bentuk intervensi untuk tindaklanjut.

Menurut standar akreditasi Rumah Sakit 2012 SKP.2 / JCI IPSG. 2 mensyaratkan agar rumah sakit menyusun cara komunikasi yang efektif, tepat waktu, akurat, lengkap, jelas, dan dapat di pahami oleh penerima. Hal ini untuk mengurangi kesalahan dan memperbaiki keselamatan pasien dimana komunikasi adalah penyebab pertama masalah keselamatan pasien (pasien safety).

Hal ini sejalan dengan penelitian yang dilakukan Agus Supiganto (2015), hasil penelitian menunjukkan bahwa sebagian besar komunikasi perawat dalam kategori baik di karekan adanya faktor yang dapat mendukung komunikasi efektif, yaitu: komunikator adalah peran sentral dari semua peran perawat yang ada dan kualitias komunikasi adalah faktor kritis dalam memenuhi kebutuhan klien.

3. Keamanan Obat

Hasil penelitian yang didapatkan berdasarkan tabel 3 tentang pelaksanaan keselamatan pasien menunjukkan bahwa keamanan obat sudah terlaksana dengan cukup baik, diketahui bahwa dari 70 responden didapatkan 66 responden $(94,3 \%)$ telah melakukan keamanan obat dengan baik, sedangkan yang tidak melakukan keamanan obat yaitu 4 responden $(5,7 \%)$.

Berdasarkan dari hasil observasi ditemukan bahwa responden sudah menerapkan keamanan obat dengan cukup baik, hal ini disebabkan karena pada hasil observasi di RSUD Labuang Baji ditemukan ada beberapa responden yang tidak mencantumkan nama obat yang perlu di waspadai (High Alert) dan obat tersebut tidak diawasi secara ketat. Namun ada sebagian responden sudah melakukan keamanan obat dimana responden telah memberi label berupa tulisan nama, umur, dan nomor kamar pasien, menyimpan obat dan cairan elektrolit lainnya terpisah dengan layanan pasien.

Obat High Alert adalah obat beriko tinggi yang menyebabkan bahaya yang bermakna bila digunakan secara salah. Obat high alert meliputi: elektroli pekat, narkotika, Obat high alert lainnya, dan sitostatika. Kebijakan obat high alert dimana setiap unit harus punya daftar obat high alert dan panduan penanganannya, setiap staf klinis terkait harus tahu penanganan obat high alert, obat high alert harus disimpan terpisah, akses terbatas, di beri lebel yang jelas, intstruksi lisan obat high alert hanya boleh dalam keadaan emergensi.

Menurut Institute for Safe Medication Practices (ISMP) obat yang perlu di waspadai ( High Alert Medication ) adalah sejumlah obat - obatan yang yang memiliki resiko tinggi menyebabkan bahaya yang besar pada pasien jika tidak digunakan secara tepat. Standar Akreditasi Rumah Sakit 2012 SKP.3 / JCI IPSG.3 mensyaratkan agar rumah sakit meningkatkan aspek keselamatan pada obat - obatan yang perlu mendapat perhatian tinggi.

Hal ini didukung dengan pedoman peningkatan keamanan obat yang perlu diwapadai, penyimpanan dan pemberian obat kepada pasien yang perlu diwaspadai termasuk elektrolit kosentrat tinggi harus memeperhatikan kaidah yaitu: setiap pemberian obat menerapkan prinsip 7 benar, pemberian elektrolit pekat harus dengan pengenceran dan penggunaan label khusus, pastikan pengenceran dan pencampuran obat dilakukan oleh orang yang berkompeten, pisahkan atau beri jarak penyimpanna obat dengan katagori LASA, tidak menyimpan obat kategori kewaspadaaan tinggi di meja dekat pasien tanpa pengawasan, biasakan mengeja nama obat dengan kategori obat LASA (look Alike Sound Alike = Nama Obat Rupa Mirip), saat memberi dan menerima instruksi.

Join Commission International dalam Standar Akreditasi Rumah Sakit (2011) yang menyatakan bahwa dalam meningkatkan keamanan obat yang perlu diwaspadai ( High alert medication) yaitu dengana adanya standar operasional prosedur sebagai kebijakan dan atau prosedur yang akan dikembangkan untuk diidentifikasi alamat, lokasi pelabelan, dan penyimpanan obat resiko tinggi, standar operasional tersebut 
diimplementasikan, konsentrat elektrolit tidak berada diruang pasien dirawat sehingga membutuhkan secara klinis dan tindakan untuk menghindari ketidaksengajaan pemberian, penyimpanan obat yang beresiko tinggi harus terpisah dan diberi label berwarna merah.

Menurut Permenkes RI No.58 Tahun 2014 tentang standar pelayanan kefarmasian di Rumah Sakit. Maka rumah sakit perlu mengembangkan kebijakan obat untuk meningkatkan keamanan, khususnya obat yang perlu diwaspadai (High alert medication)

4. Ketepatan Lokasi, Tepat Prosedur, dan Tepat Pasien Operasi

Hasil penelitian yang didapatkan berdasarkan tabel 4 tentang pelaksanaan keselamatan pasien menunjukkan bahwa ketepatan lokasi, tepat prosedur, dan tepat pasien operasi sudah terlaksana dengan baik, diketahui bahwa dari 70 responden didapatkan 70 responden (100\%) telah melakukan tepat lokasi, tepat prosedur, dan tepat pasien operasi dengan baik.

Berdasarkan dari hasil observasi ditemukan bahwa rumah sakit sudah menerapkan lembar penandaan yang jelas dan mudah di mengeti untuk identifikasi lokasi operasi dan melibatkan pasein ketika dalam keadaan sadar didalam proses penandaan. lembar penandaan yang dimaksud yaitu lembar check list dimana lembar tersebut untuk memverifikasi seperti memasikan semua dokumen atau gambar telah tersedia saat pre operasi tepat lokasi.

Tepat prosedur yaitu semua dokumentasi serta peralatan yang diperlukan sudah siap, sebelum pasien dibawa ke ruang operasi sebaiknya petugas memeriksa kembali kesiapan pasien misalnya, tanda- tanda vital, pemberian obat sebelum operasi, persiapan tranfusi darah apabila dibutuhkan dan persiapan lainnya sesuai dengan instruksi dokter dan perawat yang bertugas mencatat prosedur sign in, time out, dan sign out.

Tepat pasien yaitu pada pertama kali masuk ke ruangan operasi terlebih dahulu patugas mengkonfirmasi data pasien serta jenis operasi yang akan dilakukan terhadap pasien sesuia dengan lembar check list.

Menurut Standar Akreditasi SKP.4 RS 2012 / IPSG.4 JCI mensyaratkan agar rumah sakit memiliki kebijakan dan prosedur pembedahan yang memastikan benar lokasi, benar prosedur dan benar pasien. Hal ini sangat penting karena kesalahan lokasi kesalahan prosedur, dan kesalahan pasien saat operasi masih sering terjadi, dan berakibat fatal, oleh karena itu rumah sakit perlu menyusun dan menerapkan kebijakan dan prosedur tersebut.

Hal ini sejalan dengan penelitian Sumangkut (2017) didapatkan bahwa pada saat pasien ingin melakukan operasi Rumah Sakit Umum GMIM Kalooran Amurang menggunakan lembar check list dan melibatkan pasien dalam penandaan operasi, serta dalam observasi dokumentasi sesuai yang disampaikan informan, mereka menggunakan standar prosedur operasional yang dibuktikan dengan check list serta data pasien yang sudah dilakukan tindakan operasi.

5. Pengurangan Kejadian Infeksi

Hasil penelitian yang didapatkan berdasarkan tabel 5 tentang pelaksanaan keselamatan pasien menunjukkan bahwa pengurangan kejadian infeksi sudah terlaksana dengan cukup baik, diketahui bahwa dari 70 responden didapatkan yang terbanyak melakukan pengurangan resiko infeksi yaitu sebanyak 67 responden $(95,7 \%)$ sudah melakukan pengurangan resiko infeksi dengan menerapkan Hand hygien berdasarkan panduan dari WHO dimana bisa dijumpai di setiap ruangan maupun koridor ruamh sakit terdapat handrup yang disediakan, namun sebagian dari responden tidak melakukan pengurangan resiko infeksi yaitu sebanyak 3 responden $(4,3 \%)$.

Berdasarkan dari hasil observasi ditemukan bahwa seluruh pihak di rumah sakit menerapkan program cuci tangan yang efektif dimana penerapan ini dilakukan pada saat sebelum menyentuh pasien, sebelum melakukan tindakan antiseptik, sebelum terkontaminasi dengan cairan tubuh pasien, setelah melakukan tindakan - tindakan invasif, setelah menyentuh pasien dan setelah menyentuh daerah sekitasr pasien. Namun masih ada responden yang belum melaksanakan hand hygien, ini di sebabkan karena kurang patuhnya petugas terkait pengurangan resiko infeksi.

Hal ini sejalan dengan penelitian yang dilakukan (Susilo, 2015) bahwa dari hasil lembar observasi yang dilakukan di IGD Rumah Sakit "X" dengan menggunakan lembar observasi dan check list mendapatkan hampir semua pelaksanaan langkah -langkah dan momen mencuci tangan belum dilaksankan dengan tepat dengan persentase hanya $67 \%$.

Selain mencuci tangan untuk mencegah terjadi resiko infeksi yang perlu diperhatikan juga yaitu APD (Alat Pelindung Diri) dimana alat pelindung diri merupakan peralatan khusus yang digunakan untuk memproyeksi diri dari percikan cairan tubuh, yang berasal dari peralatan bekas pasien. APD terdiri dari masker penutup kepala, sarung tangan, pelindung wajah, pelindung kaki yang digunakan petugas untuk melindungi diri dari kontaminasi penyakit infeksi. Alat pelindung diri digunakan sesuai indikasi dan segera dilepas jika sudah selesai tindakan.

Dikutip dalam jurnal yang berjudul "Hubungan perilaku dengan kemampuan perawat dalam melaksanakan keselamtan pasien di ruang akut instalsi gawat darurat RSUP. Prof. Dr. R. Kandou Manado Fradana (2015) mengemukakan bahwa pengurangan resiko infeksi terkait pelayanan kesehatan yang paling 
gampang adalah dengan cara mencuci tangan, karena dengan mencuci tangan adalah salah satu langkah yang paling penting untuk mencegah infeksi nosokomial.

Menurut Peraturan Menteri Kesehatan Republik Indonesia Nomor 1691 / MENKES/ PER/ VIII/ 2011 tentang keselamatan pasien salah satunya adalah pengurangan resiko infeksi terkait pelayanan kesehatan. Pencegahan dan pengendalian infeksi merupakan tantangan besar dalam tatanan pelayanan kesehatan, dan menigkatkan biaya untuk mengatasi infeksi yang berhubungan dengan pelayanan kesehatan merupakan keprihatinan besar bagi pasien maupun para profesional pelayanan kesehatan.

6. Pengurangan Resiko Pasien Jatuh

Hasil penelitian yang didapatkan berdasarkan tabel 6 tentang pelaksanaan keselamatan pasien menunjukkan bahwa sudah terlaksana pengurangan resiko pasien jatuh dengan cukup baik, diketahui bahwa dari 70 responden didapatkan 64 responden $(91,4 \%)$, dan yang tidak melakukan pengurangan resiko pasien jatuh yaitu sebanyak 6 responden $(8,6 \%)$.

Berdasarkan dari hasil observasi ditemukan bahwa sebagian responden tidak menerapkan langkah langkah untuk mengurangi pasien jatuh, misalnya memasang pengaman tempat tidur, memasang gelang atau label pada pasien yang beresiko jatuh, tidak memeperhatikan lantai yang licin, pencahayaan yang kurang, dan tidak memberikan sosialisasi terhadap keluarga pasien tentang resiko pasien jatuh, namun sebagian responden sudah melakukan tindakan pengurangan resiko jatuh dimana hal tersebut sangat penting untuk tercapainya keselamatan pasien.

Upaya menurunkan resiko pasien jatuh yaitu mengidentifikasi : obat yang berhubungan dengan peningkatan resiko pasien jatuh, contohnya, sedatif, analgesik, anti hipertensi, diuretik, lazatif, psychotropika. Menggunakan protokol : pemindahan pasien secara aman, contohnya, brankar dan kursi roda. Evaluasi berapa lama respon staf terhadap panggilan pasien ( toilet, makan, dll). Gunakan instrumen untuk memprediksi resiko pasien jatuh, contohnya komunikasi dengan pasien atau kelaurga tentang resiko dan tujuan pemberian tanda atau warna. Perhatikan lingkunga : cahaya, kontrol suara atau kebisingan dan lantai yang licin.

Hal ini sejalan dengan penelitian yang dilakukan oleh Puguh Danu Sanjaya (2017), mendapatkan bahwa kurangnya sosialisasi mempengaruhi penerapan penilaian pasien resiko jatuh, karena patuh adalah taat atau tidak taat terhadap perintah, dan merupakan titik awal dari sikap dan perilaku individu.

Menurut Standar Akreditasi Rumah Sakit 2012 SKP.6/JCI IPSG.6 mensyaratkan agar rumah sakit menyusun cara untuk mengurangi pasien jatuh dan cedera akibat terjatuh. Hal ini adalah bagian dari yanggung jawab rumah sakit, karena setiap kejadian yang menimpa pasien di ramah sakit haru dianggap sebagai tanggung jawab rumah sakit. Disamping itu, kejadian pasien jatuh masih merupakan masalah yang sering dihadapi dengan akibat yang seringkali fatal.

Joint Communition Internasional dalam Standar Akreditasi Rumah Sakit (2011) yang menyatakan bahwa rumah sakit menerapkan proses assesmen awal atas pasien terhadap resiko jatuh dan melakukan assesmen ulang bila pasien diindikasikan terjadi perubahan kondisi atau pengobatan dan lain- lain. Kaji pasien resiko jatuh dengan form pengkajian resiko jatuh pada setiap pasien masuk. Lakukan Pengkajian ulang resiko jatuh padasetiap 3 hari atau sewaktu - waktu bila ada perubahan antara lain: mendapatkan medikasi baru yang dapat beresiko pasien jatuh, pasca tindakan atau prosedur yang mengurangi mobilisasi pasien, mengalami perubahan perilaku, tingkat kesadaran, dan kondisi klinis, setelah pasien jatuh, pindah dari unit satu ke unit yang lain.

\section{Kesimpulan}

1. Identifikasi pasien dalam penerapannya di RSUD Labuang Baji Makassar sudah sangat baik, dengan penerapa gelang identitas pasien.

2. Komunikasi Efektif dalam penerapanya di RSUD Labuang Baji Makassar sudah baik dengan menggunakan tekhnik SBAR dan TBAK, baik komunikasi efektif secara langsung maupun komunikasi efektif tidak langsung.

3. Keamanan obat dalam penerapannya di RSUD Labuang Baji Makassar sudah baik dimana memiliki daftar obat dan tempat penyimpanan hanya berada diruangan tertentu.

4. Pelaksaanan tepat lokasi, tepat pasien, dan tepat prosedur operasi dalam penerapannya di RSUD Labunag Baji Makassar sudah baik dengan menggunakan lembar chek list pada pasien yang ingin melakukan tindakan operasi.

5. Pengurangan resiko infeksi dalam penerapannya di RSUD Labuang Baji Makassar sudah cukup baik, dengan menggunakan metode cara mencuci tangan menurut WHO dan ketersediaananya handrup pada dinding koridor rumah sakit.

6. Pengurangan resiko infeksi dalam penerapannya di RSUD Labuang Baji Makassar sudah cukup baik, dengan menerapkan assesmen awal pada saat pasien masuk di ruangan untuk mengatasi resiko pasien jatuh, namun pada penggunaan gelang atau label belum ada. 


\section{Saran}

1. Kepada pihak RSUD Labuang Baji Makassar perlu meninjau dan mengevaluasi kembali secara langsung mengenai pelaksanan keselamatan pasien guna untuk meningkatkan pelayanan kepada masyarakat.

2. Diharpkan kepada institusi dapat memberikan bekal kompetensi bagi mahasiswa sehingga mampu memperhatikan pentingnya keselamatan pasien

3. Kepada para pembaca tidak hanya mengetahui dan memahami isi tulisan namun juga mampu memahami dan melaksanakan tentang keselamatan pasien.

\section{Ucapan Terima Kasih}

Ucapan terimakasih diberikan kepada pihak RSUD Labuang baji Makassar untuk peninjauan dan mengevaluasi guna untuk meningkatkan pelayanan kepada masyarakat dan mampu memperhatikan pentingnya keselamatan pasien.

\section{Referensi}

Kementrian Kesehatan Republik Indonesia, 2011. Keselamatan Pasien Rumah Sakit No. 1691/Menkes/Per/VIII/2011. Jakarta.

Lombogia A,(2016). "Hubungan perilaku dengan kemampuan perawat dalam melaksanakan keselamtan pasien di ruang akut instalsi gawat darurat RSUP. Prof. Dr. R. Kandou Manado.E-Jurnal Keperawatan.Vol.4 (2)

Nursalam, (2016). Metode Penelitian Ilmu Keperawatan. Jakarta. Salemba Medika

Sanjaya Puguh. (2017). Evaluasi Penerapan Pencegahan Pasien Beresiko Jatuh Di Rumah Sakit. Fakultas Kesehatan Makassar.Vol: 11 (107-115)ISSN : 1978-0575

Sumangkut, NikeS.I.(2017). Evaluasi Pelaksanaan Sasaran Keselamatan Pasien Di Rumah Sakit Umum GMIM Kalooran Amurang.

Stiyani Mardika D. (2016).Implementasi Sasaran Keselamatan Pasien Di ruang Rawat Inap RSU Kabupaten Tangerang.JKFT. (2)

Standar Akreditasi Rumah Sakit 2012, Keselamatan Pasien

Uminingsih, T. (2016). Efektiftas pelatihan patient safety dengan metode ceramah dalam meningkatkan pengetahuan perawat di rawat inap RSU PKU Muhammadiyah Bantul. Jurnal kesehatan masyarakat.9.1. (2016). 